ISSN 1561-8358 (Print)

ISSN 2524-244X (Online)

UDC 621.793:621.365:544.3

Received 25.08.2021

https://doi.org/10.29235/1561-8358-2021-66-4-399-410

Поступила в редакцию 25.08.2021

\author{
Oleg G. Devoino' ${ }^{1}$ Andrei V. Gorbunov ${ }^{2}$, Vera A. Gorbunova ${ }^{1}$, Aleksandr S. Volod'ko', \\ Vitali A. Koval ${ }^{1}$, Olga K. Yatskevich ${ }^{1}$, Anton A. Halinouski ${ }^{3}$ \\ ${ }^{1}$ Belarusian National Technical University, Minsk, Republic of Belarus \\ ${ }^{2}$ Aeronautics Institute of Technology, Sao Jose dos Campos, SP, Brazil \\ ${ }^{3}$ Institute of Atmospheric Physics of the Czech Academy of Sciences, Prague, Czech Republic
}

\title{
CHARACTERIZATION OF OPPORTUNITY FOR UPGRADING OF THE SYSTEM BASED ON ARC PLASMA TORCH FOR THERMAL SPAYING OF CERAMIC MATERIALS, BY MEANS OF USE OF FUEL VORTEX INTENSIFIER. PART I: THERMODYNAMIC MODELING OF THE SYSTEM EFFICIENCY PARAMETERS
}

Abstract. One of the main trends in the field of improving the modern technologies of thermal spraying, including plasma one, for functional ceramic coatings formation is the reducing the energy consumption of the process. In this regard, one of the important directions for improving these technologies is the development of their new versions, using the principle of adding inexpensive fuel-oxidizer mixtures based on hydrocarbons with air. This type of plasma-fuel type of spraying will be promising for application at the present time, first of all, in order to obtain refractory functional coatings. For this purpose, we investigated the opportunity for upgrading an industrial unit/system for plasma spraying of ceramic powder materials with arc plasma torch of $25-40 \mathrm{~kW}$ power by the use of experimental variant of a fuel gas-vortex intensifier. The thermodynamic assessment of possible parameters of the generated mixed flow after the torch with this fuel intensifier was carried out to estimate the applicability of this system to optimize the spraying of oxide and carbide coatings (based on the examples of $\mathrm{Al}_{2} \mathrm{O}_{3}, \mathrm{Cr}_{3} \mathrm{C}_{2}$ and other powders). The analysis of possible parameters of the produced flow after the torch with intensifier was performed for the cases of main $\mathrm{C}-\mathrm{H}-\mathrm{O}-\mathrm{N}-\mathrm{Ar}-\mathrm{Me}(\mathrm{Me}=\mathrm{Al}, \mathrm{Cr})$ systems and additional $\mathrm{C}-\mathrm{H}-\mathrm{O}-\mathrm{Al}$-system to assess the potential of this system to modify the technology of oxide and carbide ceramic coatings formation. New regimes, which were analyzed in our research as the simulants of $\mathrm{Al}_{2} \mathrm{O}_{3}$ spraying, surpass on calculated energy efficiency characteristics (by $10-20 \%$ ) one of the new prospective spraying methods with $\left(\mathrm{CO}_{2}+\mathrm{CH}_{4}\right)$-plasma, as well as the conventional method of powder heating during the spraying with $\mathrm{N}_{2}$-plasma. The case of our proposed fuel assisted process (FA-APS) with liquefied petroleum gas (LPG) fuel for the heating of ceramic powders (especially, $\mathrm{Al}_{2} \mathrm{O}_{3}$ ) demonstrates the advantage of the process (in particular, on the energy efficiencies and energy consumption) in a comparison with the conventional regimes of APS of the powders (in $\mathrm{N}_{2}$ plasma of the standard torch). For the variants of the FA-APS with $\mathrm{Al}_{2} \mathrm{O}_{3}$ and $\mathrm{Cr}_{3} \mathrm{C}_{2}$ feedstock powders it was established to be potentially possible to obtain (at the moderate values of total electric energy consumption for the torch and auxiliary equipment, - near 1.8 and $1.0 \mathrm{kWh} /(\mathrm{kg}$ of product) $)$ such high level of the process productivity on the final product as approximately 17 and $28 \mathrm{~kg} / \mathrm{h}$, respectively; at the values of required power of the torch: $\geqslant 28.2$ and $\geqslant 22.3 \mathrm{~kW}$.

Keywords: electric arc torch, combustion assisted plasma spraying, oxide and carbide powders, thermodynamics, energy efficiency, energy consumption

For citation: Devoino O. G., Gorbunov A. V., Gorbunova V. A., Volod'ko A. S., Koval V. A., Yatskevich O. K., Halinouski A. A. Characterization of opportunity for upgrading of the system based on arc plasma torch for thermal spaying of ceramic materials, by means of use of fuel vortex intensifier. Part I: Thermodynamic modeling of the system efficiency parameters. Vestsi Natsyyanal'nai akademii navuk Belarusi. Seryya fizika-technichnych navuk= Proceedings of the National Academy of Sciences of Belarus. Physical-technical series, 2021, vol. 66, no. 4, pp. 399-410 https://doi.org/10.29235/1561-8358-2021-66-4-399-410

О.Г. Девойно ${ }^{1}$, А. В. Горбунов ${ }^{2}$, В. А. Горбунова ${ }^{1}$, А. С. Володько $^{1}$, В. А. Коваль ${ }^{1}$, О. К. Яцкевич$^{1}$, А.А. Галиновский ${ }^{3}$

\footnotetext{
${ }^{1}$ Белорусский национальный технический университет, Минск, Республика Беларусь

${ }^{2}$ Технологический институт аэронавтики, Сан-Жозе-дус-Кампос, Бразилия ${ }^{3}$ Институт физики атмосферы Академии наук Чехии, Прага, Чехия
}

\section{ОПРЕДЕЛЕНИЕ ВОЗМОЖНОСТИ МОДЕРНИЗАЦИИ СИСТЕМЫ НА ОСНОВЕ ДУГОВОГО ПЛАЗМОТРОНА ДЛЯ ГАЗОТЕРМИЧЕСКОГО НАПЫЛЕНИЯ КЕРАМИЧЕСКИХ МАТЕРИАЛОВ С ИСПОЛЬЗОВАНИЕМ ТОПЛИВНОГО ВИХРЕВОГО ИНТЕНСИФИКАТОРА. ЧАСТЬ І: ТЕРМОДИНАМИЧЕСКОЕ МОДЕЛИРОВАНИЕ ПАРАМЕТРОВ ЭФФЕКТИВНОСТИ СИСТЕМЫ}

Аннотация. Одно из перспективных направлений в технологиях газотермического, в том числе плазменного, напыления функциональных керамических покрытий, - это разработка новых их вариантов, с применением ввода в теплоноситель недорогих смесей промышленных углеводородов с окислителем для снижения энергоемкости 
процесса. Такую плазменно-топливную разновидность наиболее перспективно использовать для получения тугоплавких функциональных покрытий. Для этой цели нами рассмотрена возможность модернизации промышленной системы для напыления керамических порошковых материалов на основе дугового плазмотрона на 25-40 кВт путем использования пробного варианта топливного газо-вихревого интенсификатора. При этом был проведен термодинамический анализ систем $\mathrm{C}-\mathrm{H}-\mathrm{O}-\mathrm{N}-\mathrm{Ar}-\mathrm{Me}(\mathrm{Me}=\mathrm{Al}, \mathrm{Cr})$ и $\mathrm{C}-\mathrm{H}-\mathrm{O}-\mathrm{Al}$ с целью моделирования возможных параметров генерируемой высокотемпературной струи после плазмотрона с данным интенсификатором для определения применимости такой системы для формирования оксидных и карбидных покрытий (на примере нескольких порошковых материалов, в том числе $\mathrm{Al}_{2} \mathrm{O}_{3}, \mathrm{Cr}_{3} \mathrm{C}_{2}$ ). Изученные нами новые режимы-имитаторы напыления оксида алюминия по расчетным параметрам энергоэффективности на 10-20\% превосходят как традиционный способ нагрева порошков при напылении (в $\mathrm{N}_{2}$-плазме), так и современный, разработанный в ряде исследований способ напыления в условиях смесевой $\left(\mathrm{CO}_{2}+\mathrm{CH}_{4}\right)$-плазмы. Показано, что предложенный вариант для модернизации процесса напыления с использованием промышленного пропан-бутанового топлива (сжиженного газа) позволяет в термодинамически равновесных условиях получить небольшое преимущество, по сравнению с традиционным плазменным напылением, при нагреве и плавлении керамических материалов (в особенности, $\mathrm{Al}_{2} \mathrm{O}_{3}$ ) по таким параметрам, как удельные энергозатраты и энергетические КПД процесса. Также установлено, что для расчетных случаев систем с оксидноалюминиевым и с карбиднохромовым порошками (сырьем) потенциально возможная производительность процесса по нагреваемым до плавления порошкам составляет соответственно 17 и 28 кг/ч при общих удельных энергозатратах $E C$ не выше, чем 1,8 и 1,0 кВтч/(кг продукта) и при требуемой мощности плазмотрона $\geqslant 28,2$ и $\geqslant 22,3$ кВт для нагрева этих двух вариантов сырьевых порошков.

Ключевые слова: дуговой плазмотрон, ассистируемое горением плазменное напыление, порошки, оксиды, карбиды, термодинамика, энергетический КПД, энергозатраты

Для цитирования: Определение возможности модернизации системы на основе дугового плазмотрона для газотермического напыления керамических материалов, с использованием топливного вихревого интенсификатора. Часть I: Термодинамическое моделирование параметров эффективности системы / О. Г. Девойно [и др.] // Вес. Нац. акад. навук Беларусі. Сер. фіз.-тэхн. навук. - 2021. - Т. 66, №4. - С. 399-410. https://doi.org/10.29235/1561-8358-2021-66-4-399-410

Introduction and research task. One of the most used industrial techniques for coatings formation for various functional purposes is a method of thermal spraying, which provides enhancement of wear-, thermal and corrosion resistance of the surfaces of machine parts and equipment. The world market for equipment and technologies for thermal spraying reached at the end of the 2010s a level of $\$ 10$ billion/ year, while in 2010 this value was no more than 4-5 billion [1-3]. At present, the main part (near $45 \%$ ) of thermal spraying processes is plasma ones based on the use of DC arc torches. The prevalent starting materials for thermal spraying, including plasma spray, according to the data of leading companies in this field (Oerlikon Metco AG and Praxair Surface Technologies), are powders, of which about $10^{5}$ tons are used annually. A significant part of them are ceramic powders, including $\mathrm{Al}_{2} \mathrm{O}_{3}$ ones. The disadvantages that restrain their industrial adoption (and other oxide coatings) are, along with moderate adhesion to the metal substrate and the complexity of control of the properties of coating formed, also the high energy consumption for the process $(15-35 \mathrm{kWh}$ per $\mathrm{kg}$ of sprayed material) and typically insufficient coefficient of powder utilization under the spraying due to its instable heating and limited residence time of particulates in a high temperature zone $[1,3,4]$. In this regard, one of the important directions for improvement of spraying technologies is to optimize the conditions for heat and mass transfer of powders with plasma, in particular, by optimization of operating modes of electric arc plasma torches (EAPTs) for spraying in terms of temperature and velocity characteristics and the composition of used plasma gases or their mixtures.

In the last 10 years in a number of countries (in Canada, USA, Russia, Spain, Japan) within the scope of this important trend in coating technologies, a group of new technologies have been actively developing [4-9] for electric arc spraying (at atmospheric pressure, APS) and for melting/spheroidizing of ceramic $\left(\mathrm{Al}_{2} \mathrm{O}_{3}, \mathrm{ZrO}_{2}, \mathrm{TiO}_{2}\right.$, rare earth oxides, WC) and metal (copper alloys for antibacterial coatings, heat-resistant nickel alloys) powder materials, as with the use of hydrocarbon based heat-transport gases (including $\mathrm{CH}_{4}+\mathrm{CO}_{2}$ mixtures) to improve velocity and thermal conductivity of plasma jets and to intensify particle melting in them, as well as with organic solid or liquid additives injection into plasma to control porosity and structure of sprayed coatings [10-14].

In connection with the aforementioned trends in thermal (including plasma) spraying, it seems promising to develop new processes of this type using the principle of injection (into the heat-transport medium in devices for spraying metal or oxide powders) of inexpensive fuel-oxidizer mixtures, based on alkane hydrocarbons (natural gas (NG), etc.) with air, that are efficient in terms of thermophysical 
properties, from analogy with [7,8]. In our opinion, it is expedient to use such plasma-fuel variety of spraying, first of all, to obtain such functional coatings as wear-resistant coatings of machine-building parts based on $\mathrm{Al}_{2} \mathrm{O}_{3}$, as well as carbides (of chromium, etc.), as the most demanded in recent years due to combination of technical and economic parameters for a number of factories, in particular, for the manufacturing of power plant and oil-producing equipment, including in Belarus and CIS $[1,3,7]$.

Previously, we performed the analysis using thermodynamic method for processes in $\mathrm{C}-\mathrm{H}-\mathrm{O}-\mathrm{N}-$ Me systems in the range of 300-3000 K. This problem statement allows considering them as simulators of operating gas-particulate media for technologies of oxide and metal powder processing, including spraying and powder spheroidizing [15]. This approach can be also efficient for the task stated in this research: to determine (based on theoretical assessment and subsequent experiment) the possibility for upgrading of typical for CIS systems/installations for spraying of ceramic powder materials (oxides, carbides) based on EAPT of 25-40 kW power [1,3] by means of use of trial variant of fuel gas-vortex intensifier to a level that gives a prospect for application of these systems in machine industry.

Plasma torch based spraying system, intended for the upgrading by means of use of the vortexfuel intensifier. The experimental system was developed based on standard industrial plasma spraying unit of UPU-3D type [1,3] with special fuel intensifier for testing with the injection of combination of compressed gases - nitrogen and mixture of liquefied petroleum gas (LPG) with air. A schematic diagram of a spray system of this type is illustrated in Figure 1. In this case, the operating regimes can be used with variation of power of the DC plasma torch $(P=25-35 \mathrm{~kW}$ with electric current on the arc up to 350$400 \mathrm{~A})$ as well as with variation of the composition of outlet high-temperature jets, due to the injection of $\left(\mathrm{N}_{2}+\right.$ (air + LPG)) gas mixture into the apparatus used. The mixture can be injected through the special vortex-type fuel intensifier (the body of which made from $\mathrm{Cu}-\mathrm{Zn}$ alloy $\mathrm{L63}$ ), that was designed taking into account the experience of a number of DC torches of 50-200 kW power [16-19] for plasma chemical reactors for pyrolysis and oxidation of hydrocarbons. In particular, the basic operating regime of the upgraded system based on the UPU3D unit allows, as the most preferable, such flow rate of nitrogen for plasma stabilization in the torch as $G_{\mathrm{N}_{2} \_\mathrm{pl}}=(1.0-1.2) \cdot 10^{-3} \mathrm{~kg} / \mathrm{s}$, and the flow rate of this gas for sprayed powder transportation from the feeder as $10-15 \%$ of the $G_{\mathrm{N}_{2}-\mathrm{pl}}$ value. These parameters of the proposed spraying system were further used as the initial conditions for our ther-

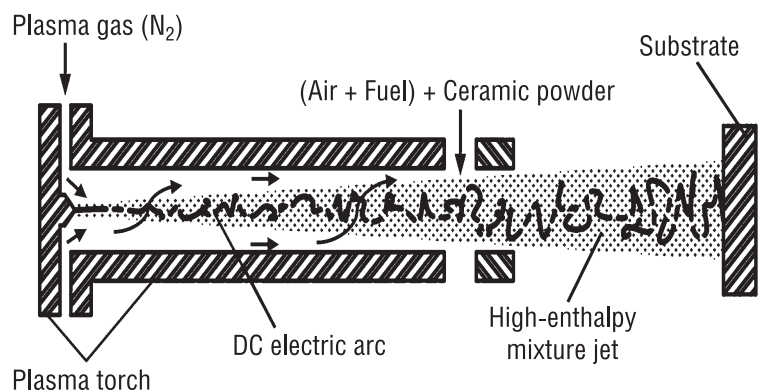

Figure 1. Schematic diagram of the analyzed processing system with ceramic powder injection, using fuel-assisted process for technology of thermal plasma spraying (APS) for oxide and carbide coatings formation modynamic calculations.

Modeling method for assessment of the parameters of high-enthalpy flow in the spraying unit based on EAPT with the fuel intensifier to determine the applicability of this system (as applied to oxide $\left(\mathrm{Al}_{2} \mathrm{O}_{3}\right)$ and carbide $\left(\mathrm{Cr}_{3} \mathrm{C}_{2}\right)$ materials). The thermochemical process with the participation of gas fuel in the reaction mixture for the basic case of $\mathrm{C}-\mathrm{H}-\mathrm{O}-\mathrm{N}-\mathrm{Me}$ systems under consideration $(\mathrm{Me}=\mathrm{Al}, \mathrm{Cr}$; in this case, the presence of an Ar impurity as air component is also advisable to take into account [20]) under the conditions of the spraying process at ambient pressure ( $p=0.101 \mathrm{MPa}$ ) is quite complicated in terms of kinetics and it can be presented by a simplified brutto-reaction (assuming that the ceramic (solid) part of the mixture, for example, oxide one, is not subjected to chemical transformations up to its melting point):

$$
\begin{gathered}
\alpha \mathrm{N}_{2} \text { (gas) }+\beta \mathrm{C}_{x_{1}} \mathrm{H}_{y_{1}} \text { (gas) }+\gamma \mathrm{N}_{x_{2}} \mathrm{O}_{y_{2}} \mathrm{Ar}_{z_{2}} \text { (gas) }+\delta \mathrm{Al}_{2} \mathrm{O}_{3} \text { (solid) }= \\
=\varepsilon \mathrm{C}_{x} \mathrm{H}_{y} \mathrm{O}_{z} \mathrm{~N}_{w} \mathrm{Ar}_{v}(\text { gas })+\delta \mathrm{Al}_{2} \mathrm{O}_{3} \text { (liquid) } .
\end{gathered}
$$

Here $\mathrm{C}_{x_{1}} \mathrm{H}_{y_{1}}$ and $\mathrm{N}_{x_{2}} \mathrm{O}_{y_{2}} \mathrm{Ar}_{z_{2}}$ are elemental formulae of technical grade LPG and air; and it was accepted that impurities of steam and $\mathrm{CO}_{2}$ in air after a compressor with standard oil-moisture separator can be neglected. Taking into account the complexity of set of redox reactions in gas phase of the system due to the possibility of several dozen compounds participation in them at different temperatures, in a general 
case the set can be represented by quite simplified brutto-reaction, which, by analogy with [19], allows partial as well as complete oxidation of alkane fuel molecules:

$$
\begin{gathered}
\mathrm{C}_{x_{1}} \mathrm{H}_{y_{1}}+n_{1} \mathrm{H}_{2} \mathrm{O}+n_{2}\left(\mathrm{O}_{2}+3.76 \mathrm{~N}_{2}\right)= \\
=p_{1} \mathrm{H}_{2}+p_{2} \mathrm{CO}+p_{3} \mathrm{H}_{2} \mathrm{O}+p_{4} \mathrm{CO}_{2}+p_{5} \mathrm{CH}_{4}+p_{6} \mathrm{~N}_{2}+p_{7} \mathrm{NO}+p_{8} \mathrm{C} \text { (solid). }
\end{gathered}
$$

The composition of selected fuel (LPG) was taken for further calculation based on the experimental data [16] for this feedstock: $\mathrm{CH}_{4}-0.6 ; \mathrm{C}_{2} \mathrm{H}_{6}-5.6 ; \mathrm{C}_{3} \mathrm{H}_{8}-72.5$; n-butane $\mathrm{C}_{4} \mathrm{H}_{10}-12.2$; iso-butane 9.0 (in vol.\%). Its averaged molecular weight is $0.0461 \mathrm{~kg} / \mathrm{mol}$, lower heating value (LHV) $=46.2 \mathrm{MJ} / \mathrm{kg}$. Taking this into account, for the reaction (1), as well as those similar to it, the values of the coefficients in elemental formulas of the reagents were established as follows: $x_{1}=3.144, y_{1}=8.288, x_{2}=1.561$, $y_{2}=0.420, z_{2}=0.0094$. Wherein, in the general case, the coefficients for elemental formula of complete heterogeneous mixture of reaction products $\mathrm{C}_{x} \mathrm{H}_{y} \mathrm{O}_{z} \mathrm{~N}_{w} \mathrm{Ar}_{y} \mathrm{Me}_{k}$ can be expressed as follows: $x=\beta \cdot x_{1}$, $y=\beta \cdot y_{1}, z=\left(\gamma \cdot y_{2}+3 \delta\right), w=\left(2 \alpha+\gamma \cdot x_{2}\right), v=\gamma \cdot z_{2}, k=2 \delta$ (for systems with $\left.\mathrm{Al}_{2} \mathrm{O}_{3}\right)$; and $x=\left(\beta \cdot x_{1}+2 \delta\right)$, $y=\beta \cdot y_{1}, z=\gamma \cdot y_{2}, w=\left(2 \alpha+\gamma \cdot x_{2}\right), v=\gamma \cdot z_{2}, k=3 \delta$ (for systems with $\mathrm{Cr}_{3} \mathrm{C}_{2}$ ).

During the thermodynamic analysis, which makes it possible to predict probable products under equilibrium and quasi-equilibrium conditions with acceptable accuracy over a wide range of temperature (up to $6000 \mathrm{~K}$ ), without considering the mechanisms of possible reactions, we used the variant of this method based on finding of entropy maximum (i. e. minimization of the Gibbs free energy/thermodynamic potential) of reacting system. The calculations were carried out using TERRA code [19, 20]. The algorithm used in it for determining the atomic/molecular composition and properties of reacting systems was presented in [15]. The data calculated were further used to analyze the efficiency of the target process of heating ceramic powders in these systems, and herewith a special group of energy and processing parameters was used, including the following ones: equivalence ratio of the mixture (on fuel) $E R[15,21]$ and its adiabatic temperature; the energy efficiency of the material heating (in various versions - with and without taking into account the contribution of fuel to the efficiency value), specific energy consumption $E C$ for the heating to desired (specified) temperature of the process, the degree of autothermicity of total allothermal process (in a variant on temperature $A D_{T}$ and in a variant on enthalpy $\left.A D_{H}\right)$ during the combined powder heating. The informativeness of these parameters was earlier tested during generalization of the characteristics of thermochemical and plasma processes, such as pyrolysis (typically requiring intensive allothermal heating via electrothermal or other routes) and gasification and combustion of a number of fuels and carbonaceous wastes, including high-ash ones [15, 21-24].

For a typical variant of heating (during spraying) of ceramic powders, in particular, oxides, the expression for such parameter as the energy efficiency $E n E_{1}$ is derived taking into account the first law of thermodynamics, and in it (in contrast to the similar efficiency for gasification of solid fuels [19, 22-24]) it is advisable to use in the numerator the enthalpy difference $\Delta H_{\mathrm{MeO}_{x}}=\left(H_{T_{3}}-H_{298}\right)_{\mathrm{MeO}_{x}}$, required to heat the oxide from temperature $T_{0}$ to the desired (specified) temperature of the process $T_{3}$, which exceeds the melting point of oxide $T_{2}$ by an amount (characterizing the degree of overheating of the reacting system beyond $T_{2}(\mathrm{DOH})$ ), which schematically represents the degree of nonadiabaticity of spraying apparatus in a zone between plasma torch nozzle (i.e. anode outlet) and the end of powder heating area (i.e. substrate for spraying). The final expression for this efficiency is the following:

$$
E n E_{1}=\frac{G_{\mathrm{MeO}_{x}} \Delta H_{\mathrm{MeO}_{x}}}{\left(G_{\mathrm{f}} L H V_{\mathrm{f}}\right)+\left[P_{\mathrm{pt}} /\left(\eta_{\mathrm{el}} \eta_{\mathrm{pt}}\right)\right]+\left[\left(\sum_{k} N_{(\mathrm{aeq}) \mathrm{k}}\right) / \eta_{\mathrm{el}}\right]} .
$$

Here $G_{\mathrm{MeO}_{x}}$ and $G_{\mathrm{f}}$ are mass flow rates for ceramic powder and for fuel, $L H V_{\mathrm{f}}$ is lower heating value of the fuel, $P_{\mathrm{pt}}$ is electric power on an arc of the torch, $N_{\text {aeq }}$ is power (or energy consumption) for each type of auxiliary electrical equipment in the system (in our case, these are: a) the power of air compressor and b) the consumption of electricity for cryogenic production of $\mathrm{N}_{2}$ as a plasma gas for the torch), $\eta_{\mathrm{pt}}$ is thermal efficiency of the torch (assumed equal to 0.80 based on aggregated data for non-transferred arc plasma torches [25]), $\eta_{\mathrm{el}}$ - energy efficiency of commercial-scale solid fuel power plants CPP of steam turbine cycle (it was chosen as 0.393 according to the actual reference data from DOE/NETL) [26]). The thermodynamic properties of the reagents $\left(\Delta H_{\mathrm{MeO}_{x}}\right.$, etc.) were determined using the NIST's database [27]. 
As additional indicators of the energy efficiency of the upgraded spraying system, we used, by analogy with [15], the energy efficiency $E n E_{2}$ (which differs from $E n E_{1}$ by ignoring the real energy efficiency of CPP (i.e. by using such efficiency magnitude as $\eta_{\mathrm{el}}=1$ ) on the efficiency value $E n E_{2}$ ), and the energy efficiency of $E n E_{3}$ (calculated, in a contrast with $E n E_{1}$, without taking into account the effect of fuel enthalpy on the last efficiency, i.e. with $G_{\mathrm{f}} \cdot L H V_{\mathrm{f}}=0$ ). The power consumption of the compressor for air blowing into the spraying system was calculated as in the paper [28], at the polytropic index of 1.40. Also, for the "basic" (further labeled as "bas") regimes (in $\mathrm{N}_{2}$, that simulates the conditions of industrial spraying units $[1,3]$ without fuel in plasma flow) of powder processing, we took account of the energy consumption for production of $\mathrm{N}_{2}$ from air, and by analogy with [29] it was assumed to be at the level of $0.3 \mathrm{~kW} \cdot \mathrm{h} / \mathrm{kg}$ (ignoring the contribution of the CPP efficiency).

The adiabatic temperature $T_{\mathrm{ad}}$ of a mixture of given composition under equilibrium and quasi-equilibrium conditions can be calculated in the mass-average approximation based on the dependences derived from the law of conservation of energy [15, 24]. Specific consumption of electric energy (in kWh (for all types of equipment in the system) per kg of final ceramic material) in systems of the type under consideration (excluding the contribution of the CPP efficiency) was calculated as $E C=\left(P_{\mathrm{pl}} / \eta_{\mathrm{pt}}+\sum N_{\mathrm{aeq}}\right) / G_{\mathrm{MeO} x}$; and the degree of overheating $(\mathrm{J} / \mathrm{J})$ of the reacting system beyond $T_{2}$ (i.e., to the desired specified temperature of the process $\left.T_{3}\right)$ as: $\mathrm{DOH}=\left(I_{\mathrm{pr}}\left(T_{2}\right)-I_{\mathrm{pr}}\left(T_{0}\right)\right) /\left(I_{\mathrm{pr}}\left(T_{1}\right)-I_{\mathrm{pr}}\left(T_{0}\right)\right)$. Here, $I_{\mathrm{pr}}(T)$ denotes three variants of the sum of enthalpies of the equilibrium products of interaction (taking into account their molar fractions $M_{i}$ in the reacting mixture): at high temperatures $T_{2}$ and $T_{3}$, and at initial $T_{0}=298.15 \mathrm{~K}$.

For most general case of the considered APS process (assuming the use of thermally dissociated feedstock/material in it), the energy balance for the main (thermochemical) zone under the spraying of ceramic (e.g. oxide) material, during which the target transformation takes place (including possible chemical dissociation reaction and the phase transition, i.e. melting of oxide) can be written as:

$$
N_{0}=Q_{\mathrm{hm}}+Q_{\mathrm{w}}+Q_{\mathrm{ex}}=\left(\Delta H_{1}^{m}+\Delta H_{2}^{m}+\Delta H_{3}^{m}+\Delta H_{4}^{m}+\Delta H_{5}^{m}\right)+Q_{\mathrm{w}}+Q_{\mathrm{ex}} .
$$

Here in the considered general case of this air-plasma APS-process (in which, as an option, heating of the powder of thermally dissociating feedstock/material is allowed), the total temperature range for the sprayed substance (which, for the case, e.g. of obtaining a coating from $\mathrm{Al}_{2} \mathrm{O}_{3}$ with estimated value of melting point of $2328 \mathrm{~K}$ [27], ranges approximately from 298.15 to $2500 \mathrm{~K}$ ) is divided to the regions: 1) from $T_{0}=298.15 \mathrm{~K}$ to the temperature of feedstock decomposition (to final oxide), equal to $T_{1} ; 2$ ) from $T_{1}$ to melting point of oxide particles $T_{2} ; 3$ ) from $T_{2}$ to the maximum temperature $T_{3}$ reached by molten particles in front of metal substrate. In the equation (4), for the process thermochemical zone (including quasi-cylindrical section between the outlet from the torch anode and the substrate), the following unit symbols are used: total thermal power (in W) of the feedstock and the heat-transport gas at the inlet to the zone under consideration: $N_{0}=Q_{\mathrm{hc}}+N_{\mathrm{hm}}=Q_{\mathrm{hc}}+\sum_{j}\left(M_{j} H_{j}\right)$ (where $Q_{\mathrm{hc}}$ is the thermal power of the material (if it is injected as preheated one), $N_{\mathrm{hm}}$ is the thermal power of the heat transport gas, i.e. plasma gas, preheated by the torch arc); $Q_{\mathrm{hm}}$ - "useful" heat, transferred from hot gas in the considered jet to the initial particulates heated to melting (which depends on the material can be exposed to dissociation, as, e.g. in the techniques of special APS-, SPS-, SolPS-spraying $[9,14,30]) ; Q_{\mathrm{w}}-$ heat losses from gas-powder flow in the considered zone in radial direction to surrounding air or to the walls of the protective channel (in the case of flow inside the channel (e.g. shroud, as it was in the oxy-fuel spraying [31])); $Q_{\text {ex }}$ is the heat power of the gas phase of this high-enthalpy jet at the exit from the considered zone after the end of powder melting, which decreases during the following heat transfer with substrate; $\Delta H_{1}^{m}=\left(H_{T_{1}}^{0}-H_{T_{0}}^{0}\right)_{\mathrm{hm}}$, is the difference between the enthalpy of the initial material (undissociated) at $T_{1}$ (e.g., for the case of $\mathrm{Al}(\mathrm{OH})_{3}$ equal to $\sim 550 \mathrm{~K}$ [32]) and its enthalpy at $T_{0} ; \Delta H_{2}^{m}=\Delta H_{\mathrm{dr} 298}^{0}$ is the heat of dissociation reaction (endothermic) of the initial feedstock powder (e.g. with the formation of oxide) at $T_{1}$; $\Delta H_{3}^{m}=\left(H_{T_{2}}^{0}-H_{T_{1}}^{0}\right)_{\mathrm{hm}}$ is the difference between the enthalpy of dissociated powder at the $T_{2}$ and its enthalpy at $T_{1} ; \Delta H_{4}^{m}=\left(\Delta_{\mathrm{f}} H_{\text {liquid }}^{0}-\Delta_{\mathrm{f}} H_{\text {solid }}^{0}\right)=\Delta H_{\text {melt }}^{0}-$ is the heat (normalized to the standard conditions) of powder melting at $T_{2} ; \Delta H_{5}^{m}=\left(H_{T_{3}}^{0}-H_{T_{2}}^{0}\right)_{\mathrm{hm}}$ is the difference between the enthalpy of final powder at $T_{3}$, slightly higher (usually, for technological reasons, by 150-300 K) the $T_{2}$, and its enthalpy at $T_{2}$. 
404 Proceedings of the National Academy of Sciences of Belarus. Physical-technical series, 2021, vol. 66, no. 4, pp. 399-410

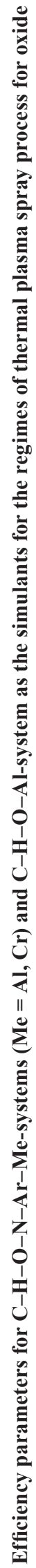

\begin{tabular}{|c|c|c|c|c|c|c|c|c|c|c|c|c|c|c|c|c|c|c|c|c|c|c|c|c|c|c|}
\hline & 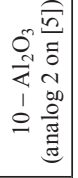 & & ن & 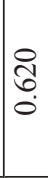 & 옹 & 童 & $\begin{array}{l}0 \\
\vdots \\
\vdots \\
\dot{b}\end{array}$ & $\begin{array}{l}8 \\
\stackrel{2}{2} \\
i\end{array}$ & $\tilde{m}$ & 0 & & $\begin{array}{l}\tilde{b} \\
\vdots \\
\infty \\
\infty\end{array}$ & 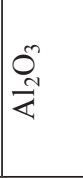 & $\frac{n}{n}$ & 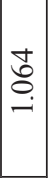 & $\begin{array}{c}1 \\
0 \\
0 \\
0\end{array}$ & 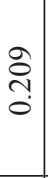 & 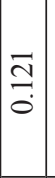 & $\begin{array}{l}\stackrel{i}{q} \\
\dot{0} \\
\dot{m}\end{array}$ & $\begin{array}{l}\tilde{c} \\
\tilde{o} \\
0\end{array}$ & $\begin{array}{l}\infty \\
\stackrel{2}{0} \\
\dot{0}\end{array}$ & $\begin{array}{l}\text { oे } \\
\text { + } \\
\dot{+}\end{array}$ & $\begin{array}{l}\vec{n} \\
\infty \\
\sigma\end{array}$ & $\mid \begin{array}{l}\vec{N} \\
\infty \\
\infty\end{array}$ & 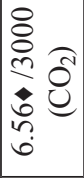 & $\underset{\vec{v}}{\stackrel{\sim}{+}}$ \\
\hline & 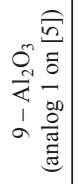 & & 焉 & 离 & $\begin{array}{l}\stackrel{1}{0} \\
0 \\
0\end{array}$ & 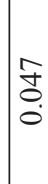 & 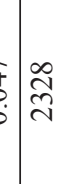 & $\begin{array}{l}8 \\
\stackrel{2}{n} \\
\approx\end{array}$ & $\mid \begin{array}{c}\hat{n} \\
\dot{m}\end{array}$ & 0 & & 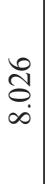 & 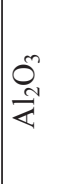 & $\underset{m}{\stackrel{R}{m}}$ & $\mid \begin{array}{l}0 \\
0 \\
0 \\
-1 \\
-1\end{array}$ & $\stackrel{ \pm}{=}$ & \begin{tabular}{c} 
İ \\
\multirow{2}{o}{}
\end{tabular} & 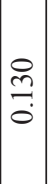 & $\begin{array}{l}\bar{m} \\
\infty \\
i\end{array}$ & $\begin{array}{l}m \\
\hat{0} \\
0\end{array}$ & $\begin{array}{l}2 \\
\hat{0} \\
0 \\
0\end{array}$ & 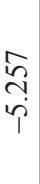 & $\stackrel{\bullet}{\rightleftarrows}$ & $\begin{array}{l}\overrightarrow{0} \\
\infty \\
0\end{array}$ & 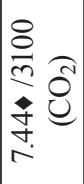 & $\begin{array}{l}\overrightarrow{\vec{\infty}} \\
\dot{m}\end{array}$ \\
\hline & 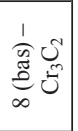 & & 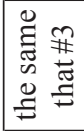 & $\begin{array}{l}8 \\
8 \\
\infty \\
0\end{array}$ & $\begin{array}{l}8 \\
0 \\
\infty \\
0\end{array}$ & 0 & $b \stackrel{\infty}{\stackrel{\infty}{\sim}}$ & $\begin{array}{l}8 \\
\curvearrowright \\
\approx\end{array}$ & $\underset{F}{-}$ & 0 & & 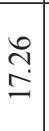 & 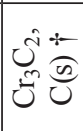 & $\stackrel{\curvearrowright}{\curvearrowright}$ & $\Xi$ & 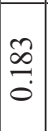 & \begin{tabular}{l}
$\hat{0}$ \\
\multirow{0}{*}{} \\
0
\end{tabular} & $\mid \begin{array}{c}\infty \\
\infty \\
0 \\
0\end{array}$ & $\stackrel{n}{0}$ & 0 & 0 & 0 & 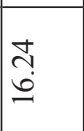 & $\begin{array}{l}\qquad \tilde{b} \\
\dot{\sim}\end{array}$ & $\mid \begin{array}{ll}+ & 8 \\
0 & 8 \\
0 & 0 \\
0 & \text { in }\end{array}$ & 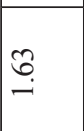 \\
\hline & $\begin{array}{c}U_{-}^{2} \\
\vdots \\
1 \\
-1\end{array}$ & & 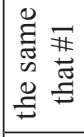 & $\mid \begin{array}{l}8 \\
8 \\
\infty \\
0\end{array}$ & $\begin{array}{l}8 \\
0 \\
\infty \\
0\end{array}$ & $\bar{\sigma}$ & $\begin{array}{l}5 \\
\dot{b} \\
\dot{0}\end{array}$ & 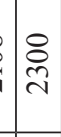 & $\vec{F}$ & $\begin{array}{l}8 \\
8 \\
n \\
0\end{array}$ & & $\begin{array}{l}\tilde{b} \\
\ddot{m} \\
\ddot{n}\end{array}$ & 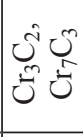 & $\hat{N}$ & $\stackrel{0}{0}$ & $\stackrel{2}{\stackrel{2}{0}}$ & $\stackrel{m}{\vec{\sigma}}$ & $\mid \begin{array}{c}\sigma \\
\sigma \\
0\end{array}$ & 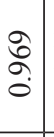 & $\begin{array}{l}\text { ते } \\
\text { ஸे } \\
0\end{array}$ & $\frac{ \pm}{ \pm}$ & $\underset{i}{\stackrel{\infty}{i}}$ & $\begin{array}{l}\dot{\sigma} \\
\stackrel{2}{0}\end{array}$ & 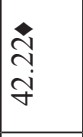 & $\mid$\begin{tabular}{ll}
$\infty$ & 8 \\
\hdashline & 8 \\
2 & 0
\end{tabular} & \& \\
\hline & $\begin{array}{l}0 \\
0 \\
1 \\
1 \\
0\end{array}$ & & 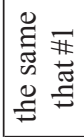 & $\begin{array}{l}8 \\
0 \\
0 \\
0 \\
0\end{array}$ & $\begin{array}{l}8 \\
0 \\
\infty \\
0 \\
0\end{array}$ & $\stackrel{m}{\circ}$ & 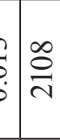 & 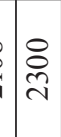 & $\underset{-}{-}$ & $\begin{array}{l}8 \\
0 \\
0 \\
0\end{array}$ & & $\begin{array}{l}n \\
\infty \\
\grave{\sim}\end{array}$ & $\begin{array}{l}U_{0}^{N} \\
\tilde{U}\end{array}$ & જ) & $\stackrel{ }{\exists}$ & $\frac{N}{\stackrel{N}{0}}$ & $\begin{array}{l}\stackrel{2}{\circ} \\
\text { ஸे }\end{array}$ & $\mid$ & \begin{tabular}{l|}
8 \\
$\vdots$ \\
\hdashline
\end{tabular} & $\begin{array}{l}\stackrel{8}{\circ} \\
\text { ஸे }\end{array}$ & \begin{tabular}{l}
0 \\
\hdashline \\
0 \\
0
\end{tabular} & $\begin{array}{l}\infty \\
0 \\
\dot{p} \\
\dot{1}\end{array}$ & $\stackrel{\vec{n}}{\stackrel{\sim}{\sim}}$ & 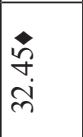 & 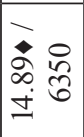 & 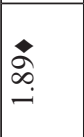 \\
\hline & 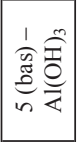 & & 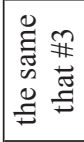 & $\begin{array}{l}\stackrel{0}{2} \\
0 \\
0\end{array}$ & ণิ & 0 & $b \mid \begin{array}{l}\infty \\
\tilde{N} \\
\tilde{N}\end{array}$ & \begin{tabular}{l}
8 \\
\hdashline \\
2
\end{tabular} & $\begin{array}{l}\stackrel{*}{厶} \\
\infty \\
\dot{n} \\
\dot{n}\end{array}$ & 0 & & $\begin{array}{l}\stackrel{ \pm}{\sim} \\
i \\
i\end{array}$ & 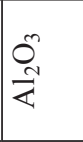 & 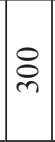 & $\stackrel{0}{\varrho}$ & $\frac{1}{2}$ & $\begin{array}{c}\bar{\sigma} \\
\tilde{0}\end{array}$ & $\mid \begin{array}{c}: \\
\stackrel{2}{0} \\
0\end{array}$ & 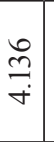 & 0 & 0 & 0 & in & in & 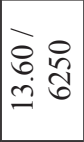 & $\hat{n}$ \\
\hline & 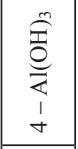 & & 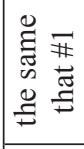 & $\mid \begin{array}{l}0 \\
0 \\
0 \\
0\end{array}$ & ֻै & $\vec{\sigma}$ & $\begin{array}{l}b \\
\vdots \\
\vdots \\
\vdots \\
\tilde{N}\end{array}$ & $\begin{array}{l}8 \\
\stackrel{2}{2} \\
i\end{array}$ & $\begin{array}{l}\stackrel{*}{厶} \\
\infty \\
\stackrel{\infty}{n}\end{array}$ & $\begin{array}{l}8 \\
8 \\
n \\
0 \\
0\end{array}$ & & $\stackrel{\nearrow}{\sim}$ & 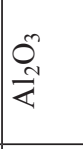 & $\mid \begin{array}{l}n \\
0 \\
n\end{array}$ & $\begin{array}{l}\infty \\
\stackrel{\infty}{0} \\
-\end{array}$ & 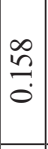 & $\begin{array}{l}n \\
\infty \\
n \\
0\end{array}$ & $\mid \begin{array}{l}\mathbb{0} \\
\stackrel{0}{0} \\
0\end{array}$ & $\begin{array}{l}\infty \\
\infty \\
\infty \\
\dot{n}\end{array}$ & $\begin{array}{l}0 \\
\text { ô. } \\
0\end{array}$ & $\begin{array}{l}\Re \\
0 \\
0 \\
0 \\
0\end{array}$ & $\begin{array}{l}m \\
\stackrel{m}{m} \\
\end{array}$ & 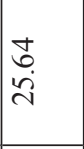 & $\begin{array}{l}\vec{n} \\
n \\
n\end{array}$ & 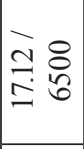 & $\stackrel{?}{\stackrel{r}{m}}$ \\
\hline & 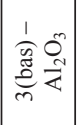 & 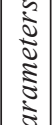 & ¿ & 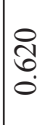 & 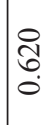 & 0 & $b \mid \begin{array}{l}\infty \\
\sim \\
\sim \\
\sim\end{array}$ & $\begin{array}{l}8 \\
2 \\
2\end{array}$ & $\hat{n}$ & 0 & 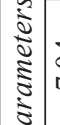 & $\underset{⿱}{\stackrel{D}{r}}$ & 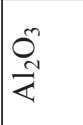 & $\stackrel{\infty}{\stackrel{2}{2}}$ & $\begin{array}{l}0 \\
0 \\
0 \\
- \\
-\end{array}$ & $\frac{n}{a}$ & \begin{tabular}{l}
0 \\
\multirow{2}{*}{} \\
\multirow{2}{*}{} \\
0
\end{tabular} & $\begin{array}{c}\stackrel{2}{c} \\
\stackrel{0}{0}\end{array}$ & $\begin{array}{l}\overrightarrow{0} \\
\vec{i}\end{array}$ & 0 & 0 & 0 & $\begin{array}{l}\stackrel{g}{\vec{q}} \\
\stackrel{2}{2}\end{array}$ & 方 & 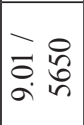 & $\hat{n}$ \\
\hline & $\begin{array}{c}0_{1}^{\infty} \\
\stackrel{N}{4} \\
1 \\
\sim\end{array}$ & 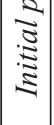 & 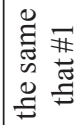 & 怘 & $\begin{array}{l}\text { त्रे } \\
\text { ¿. }\end{array}$ & $\begin{array}{l}\frac{m}{0} \\
0 \\
0\end{array}$ & 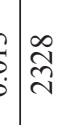 & $\begin{array}{l}8 \\
\stackrel{2}{2}\end{array}$ & $\hat{n}$ & $\begin{array}{l}0 \\
0 \\
-1 \\
-1\end{array}$ & 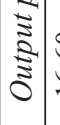 & $\begin{array}{l}\dot{0} \\
\dot{0} \\
\dot{0}\end{array}$ & 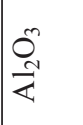 & $\hat{\infty}$ & 砱 & $\frac{\hat{a}}{3}$ & $\begin{array}{l}\bar{b} \\
+ \\
0 \\
0\end{array}$ & 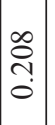 & $\underset{\mathbb{N}}{\stackrel{N}{ }}$ & \begin{tabular}{l}
$\stackrel{n}{+}$ \\
\multirow{2}{o}{}
\end{tabular} & $\begin{array}{c}\infty \\
\stackrel{\infty}{0} \\
\end{array}$ & $\begin{array}{l}\stackrel{a}{\imath} \\
\stackrel{1}{T}\end{array}$ & $\begin{array}{l}\hat{\imath} \\
\infty \\
\infty \\
i\end{array}$ & 命 & $\begin{array}{ll}\ddagger & 0 \\
\infty & 0 \\
\infty & 0 \\
\infty & 0\end{array}$ & $\stackrel{n}{i}$ \\
\hline & $\begin{array}{l}0_{N} \\
\stackrel{4}{<} \\
I\end{array}$ & & 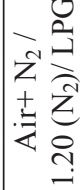 & ○̊ & $\begin{array}{l}8 \\
: \\
? \\
0\end{array}$ & $\stackrel{1}{\circ}$ & 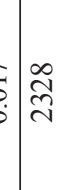 & $\begin{array}{l}\stackrel{8}{2} \\
\stackrel{2}{1}\end{array}$ & $\hat{m}$ & 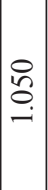 & & $\stackrel{\Xi}{0}$ & 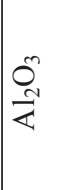 & $\approx$ & \begin{tabular}{l}
8 \\
0 \\
\hdashline \\
-
\end{tabular} & $\mid \begin{array}{c}\frac{1}{6} \\
0 \\
0\end{array}$ & $\begin{array}{l}\vec{\infty} \\
\tilde{0} \\
0\end{array}$ & $\mid \begin{array}{c}\vec{\infty} \\
\overrightarrow{0}\end{array}$ & $\begin{array}{l}\hat{0} \\
\hat{i} \\
\hat{i}\end{array}$ & $\frac{2}{3}$ & 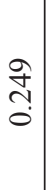 & \begin{tabular}{l}
$n$ \\
$\stackrel{2}{0}$ \\
\hdashline
\end{tabular} & $\stackrel{\infty}{\stackrel{\infty}{a}}$ & $\begin{array}{l}m \\
\infty \\
\infty \\
\sim\end{array}$ & 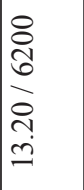 & $\stackrel{\stackrel{N}{\sim}}{\stackrel{\sim}{v}}$ \\
\hline & & & 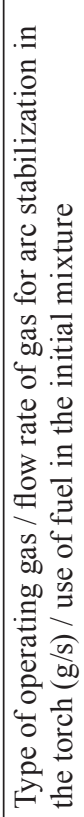 & 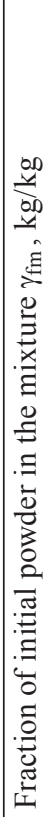 & 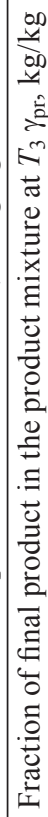 & 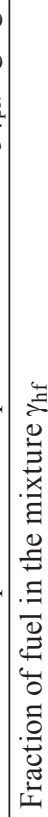 & 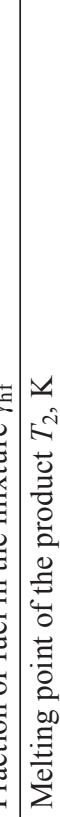 & 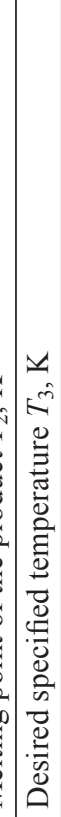 & 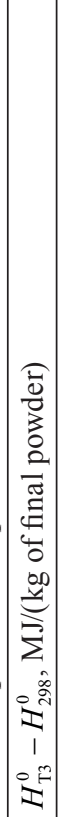 & 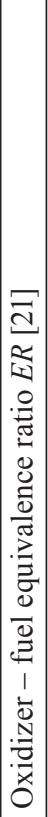 & & 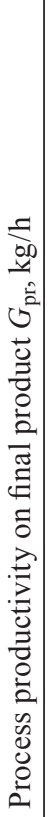 & 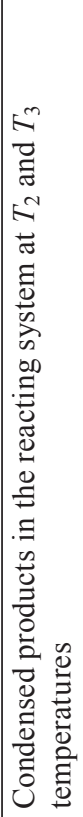 & 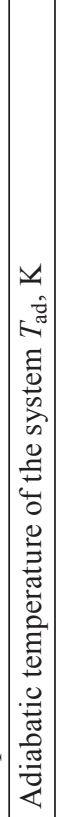 & 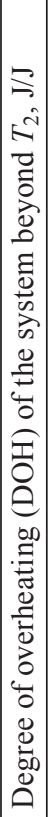 & 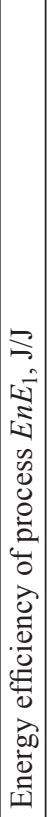 & 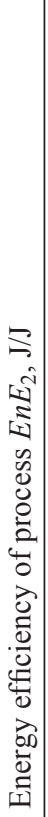 & 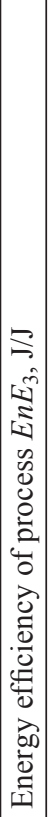 & 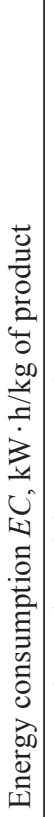 & 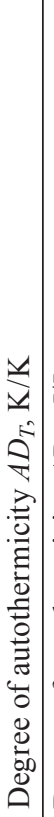 & 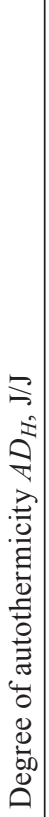 & 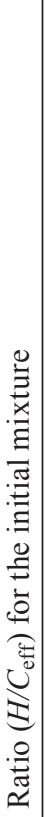 & 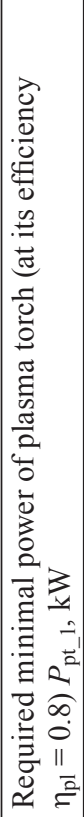 & 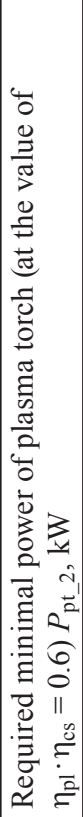 & 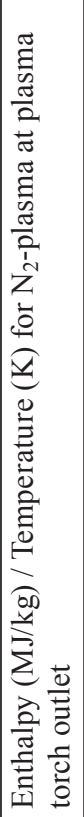 & 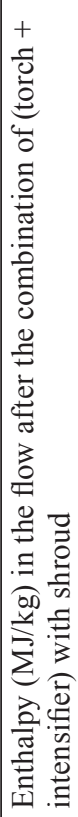 \\
\hline
\end{tabular}


Footnote for the Table.

Unit symbols for the parameters:

mass fraction of fuel in the mixture $-\gamma_{\mathrm{hf}}$;

process productivity on final product (i.e. oxide or carbide powder material) $-G_{\mathrm{pr}}$;

mass fraction of final product/material in the product mixture at $T_{3}-\gamma_{\mathrm{pr}}$;

the difference between the enthalpies of final ceramic material (as $(*)$ the case of APS-process with $\mathrm{Al}(\mathrm{OH})_{3}$-feedstock was marked, which differs by the taking account of energy consumption for feedstock heating up to its dissociation to oxide) at final temperature $T_{3}$ and at initial $T_{0}$ for the reacting mixture $-\left(H_{\mathrm{T} 3}^{0}-H_{298}^{0}\right)$;

the equivalence ratio for analyzed reacting mixture $E R=\left(G_{\mathrm{ox}} / G_{\mathrm{f}}\right) / R_{\mathrm{st}}$ (where $G_{\mathrm{ox}} / G_{\mathrm{f}}-$ ratio of the mass flow rates of oxidizer and fuel for the mixture; $R_{\mathrm{st}}$ - ratio of the flow rates of these reagents in the stoichiometric mixture, which is sufficient for complete fuel oxidation);

energy efficiency for the heating of initial material in the mixture (ignoring the contribution of CPP' efficiency) $-E n E_{2}$;

energy efficiency for the heating of initial material (ignoring the contribution of the fuel enthalpy in the heating process) $-E n E_{3}$; degree of autothermicity of the reacting system on temperature $-A D_{T}(\mathrm{~K} / \mathrm{K})$ and on enthalpy $-A D_{H}(\mathrm{~J} / \mathrm{J})$;

effective hydrogen to carbon ratio for initial reacting mixtures with varied chemical composition [33] $-\left(H / C_{\text {eff }}\right)$;

required minimal power of plasma torch (at total energy efficiency of the combination "torch + attached protective "shroud" $\left.\eta_{\mathrm{pl}} \cdot \eta_{\mathrm{cs}}=0.6\right)-P_{\mathrm{pt} \_}$;

Symbols:

$\dagger-$ micro-impurity ( $\leqslant 1 \%$ of total mass of condensed products), - with taking account of effect of heating value $(H H V)$ of fuels in these POA-APS-regimes as for complete combustion.

Results of the modeling. The calculated efficiency parameters for $\mathrm{C}-\mathrm{H}-\mathrm{O}-\mathrm{N}-\mathrm{Ar}-\mathrm{Me}$ systems $(\mathrm{Me}=\mathrm{Al}, \mathrm{Cr} ; p=0.101 \mathrm{MPa})$ are shown in Table as for the simulants of operating regimes of the plasma spraying system (APS-process) for oxide and carbide coatings, using proposed fuel intensifier, for two variants on injected fuel evolution: a) regimes with complete oxidation (i.e. combustion) assistance (CA-APS), b) regimes with its partial oxidation assistance (POA-APS). Figures 2-4 represent the examples of data obtained on the compositions during heating of the reacting systems for two variants (CAand POA-APS) for the cases that simulate thermodynamically optimal conditions for processing regimes with $\mathrm{Al}_{2} \mathrm{O}_{3}$ and $\mathrm{Cr}_{3} \mathrm{C}_{2}$ (the condensed phases are indicated by the symbol "c" in the graphs). For the cases that are identical to the ones in the Table, but without metals (i.e. C-H-O-N-Ar-system, see their compositions in Figure 5), it was found that for the regime with $E R=1.0$ (CA-APS-process) temperature $T_{\text {ad }}=1597 \mathrm{~K}$ and at $E R=0.30$ (POA-APS-process) the value $T_{\text {ad }}=938 \mathrm{~K}$. Besides, in Figure 6 the dependences for total enthalpies of analyzed $\mathrm{C}-\mathrm{H}-\mathrm{O}-\mathrm{N}-\mathrm{Ar}-\mathrm{Al}-, \mathrm{C}-\mathrm{H}-\mathrm{O}-\mathrm{N}-\mathrm{Ar}-\mathrm{Cr}-$ and $\mathrm{C}-\mathrm{H}-\mathrm{O}-\mathrm{Al}$-systems are presented. The regimes investigated, which simulate the spraying of oxides (on the example of $\mathrm{Al}_{2} \mathrm{O}_{3}$ from two kinds of feedstock), surpass (by 5-20\%) on calculated output characteristics, such as energy efficiencies and energy consumption for heating, the conventional method of powder heating during the spraying with $\mathrm{N}_{2}$-plasma (especially, case with $\mathrm{Al}_{2} \mathrm{O}_{3}$ powder), as well as one of the new methods with $\left(\mathrm{CO}_{2}+\mathrm{CH}_{4}\right)$-plasma [5-6, 9], - see the Table for comparison of the regimes: 2 with $3 ; 4$ with $5 ; 9$.

In Figure 7 the comparison of the part of the found efficiency parameters is presented for various cases of the modeled systems as the simulants for regimes of plasma spray with the fuel assistance. It is evidently from the Figure 7 as well as from the results of the Table, that the case of proposed FA-APS
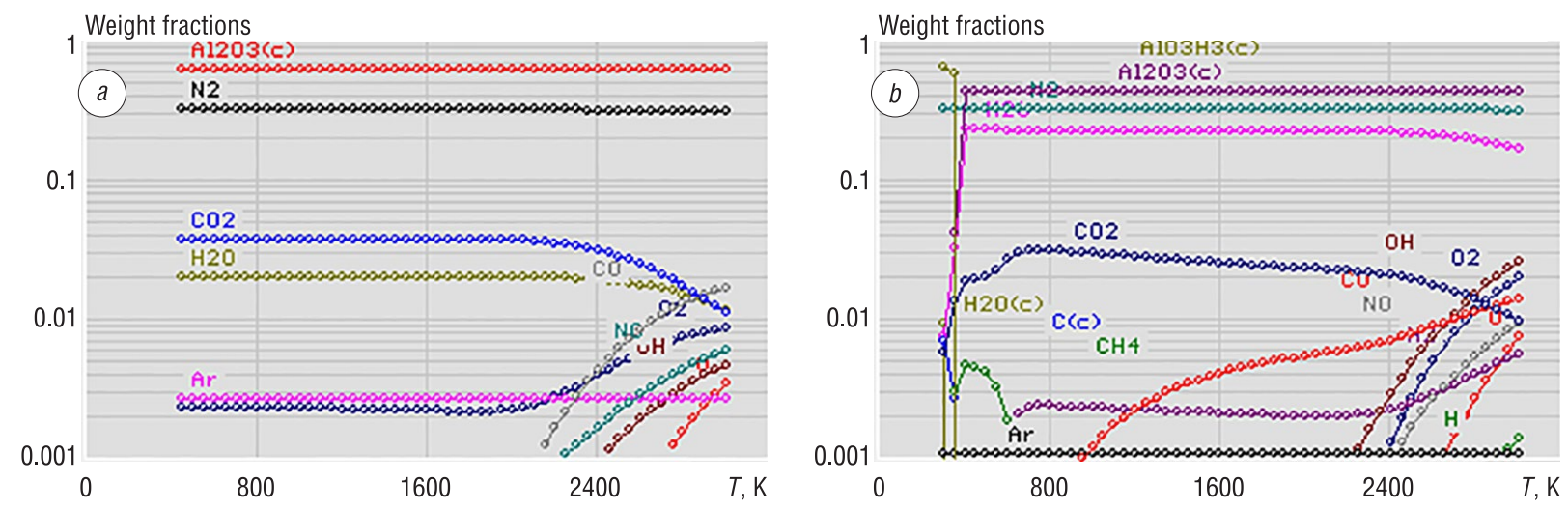

Figure 2. Calculated chemical compositions for equilibrium systems $\mathrm{C}-\mathrm{H}-\mathrm{O}-\mathrm{N}-\mathrm{Ar}-\mathrm{Al}$ at $T=300-3000 \mathrm{~K}(p=0.101 \mathrm{MPa})$ with the ratios of initial reagents corresponding to model regimes of alumina coating spraying with use of initial $\mathrm{Al}_{2} \mathrm{O}_{3}$ powder $(a)$ in oxidative gas medium at the equivalence ratio $E R=1.05$ (see regime 2 in the Table), and with initial $\mathrm{Al}(\mathrm{OH})_{3}$ feedstock powder $(b)$ in combined reducing-oxidative medium at $E R=0.50$ (see regime 4 in the Table) 


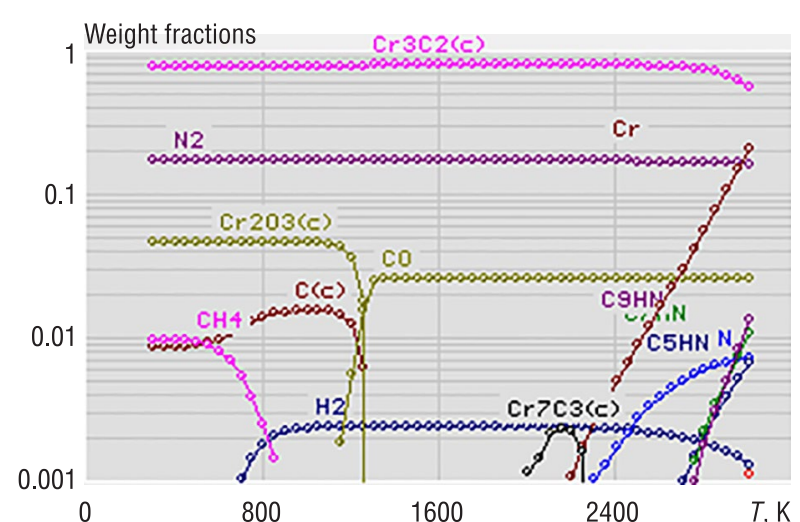

Figure 3. Calculated composition for quasi-equilibrium system C-H-O-N-Ar-Cr at $T=300-3000 \mathrm{~K}(p=0.101 \mathrm{MPa})$ with the ratios of initial reagents corresponding to the model regime of carbide coating spraying with use of initial $\mathrm{Cr}_{3} \mathrm{C}_{2}$ powder in reducing gas medium, which is achievable at the conditions of partial oxidation of LPG (see regime 6 in the Table) at the mixture equivalence ratio $E R=0.30$. (In this calculation the absence of $\mathrm{CrN}$ and $\mathrm{Cr}_{2} \mathrm{~N}$ phases was specified for kinetic reasons of the initial carbide-contained heterogeneous systems of this group at $T \leqslant 1200 \mathrm{~K}$ [4])

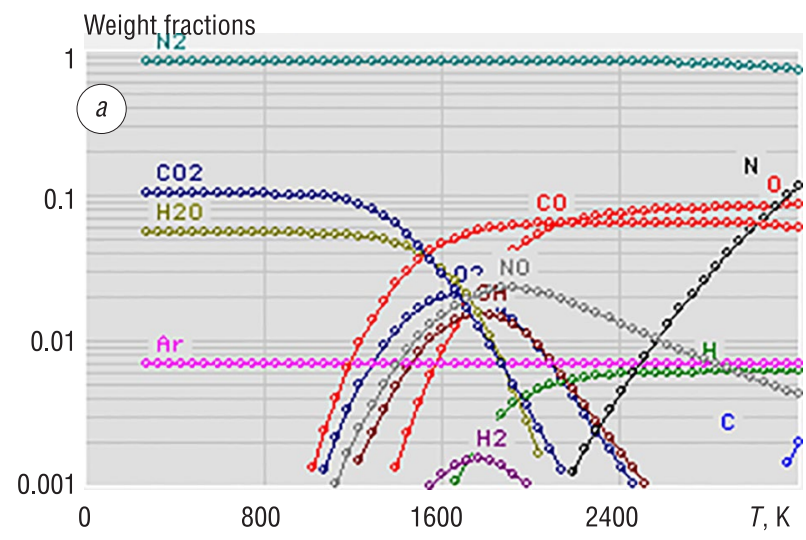

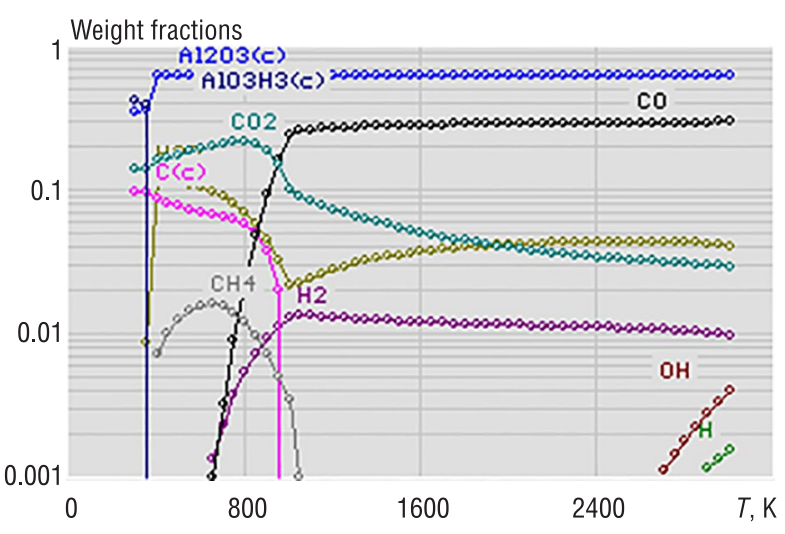

Figure 4. Calculated composition for equilibrium system $\mathrm{C}-\mathrm{H}-\mathrm{O}-\mathrm{Al}$ at $T=300-3000 \mathrm{~K}(p=0.101 \mathrm{MPa})$ with the proportion of initial reagents, that is simulating the experiment, which is analogue of our proposed plasma-fuel spray process and was performed by the authors [5] with the effect of complete melting of alumina powder in the DC plasma torch jet in reducing medium in the mixture of $\left(\mathrm{Al}_{2} \mathrm{O}_{3}+\mathrm{CO}_{2}+\mathrm{CH}_{4}\right)$ at the conditions of partial oxidation of the alkane fuel (see regime 10 in the Table)

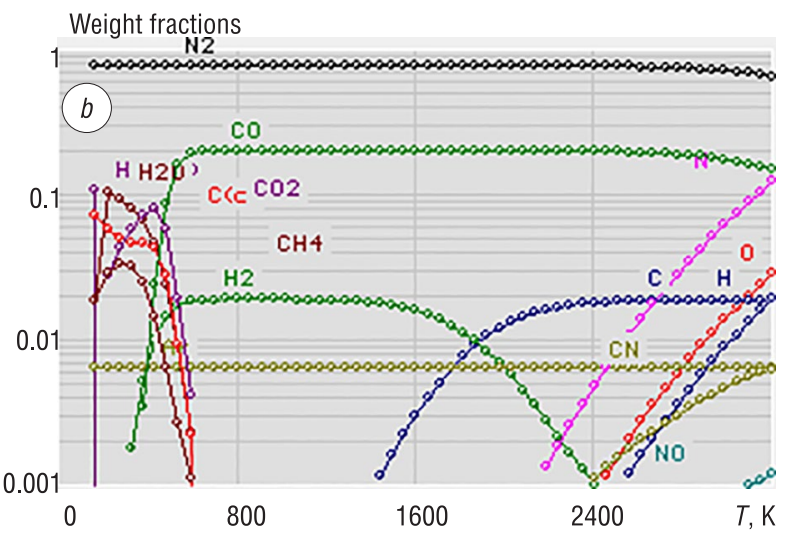

Figure 5. Composition for equilibrium systems $\mathrm{C}-\mathrm{H}-\mathrm{O}-\mathrm{N}-\mathrm{Ar}$ (without metals) for the range of 300-6000 K ( $p=0.101 \mathrm{MPa}$ ), with the ratios of initial components corresponding to the regimes, which are applicable for deposition of ceramic coatings: in the oxidizing medium formed by the " $\mathrm{N}_{2}+$ air + LPG fuel"-mixture (CA-APS-process) at the equivalence ratio $E R=1.00$ and $T_{\text {ad }}=$ $1597 \mathrm{~K}(a)$, and in the reducing medium formed by the similar mixture (POA-APS-process) at $E R=0.30$ and $T_{\mathrm{ad}}=938 \mathrm{~K}(b)$. For these regimes the nitrogen flow rate $G_{\mathrm{N} 2}=1.2 \cdot 10^{-3} \mathrm{~kg} / \mathrm{s}$

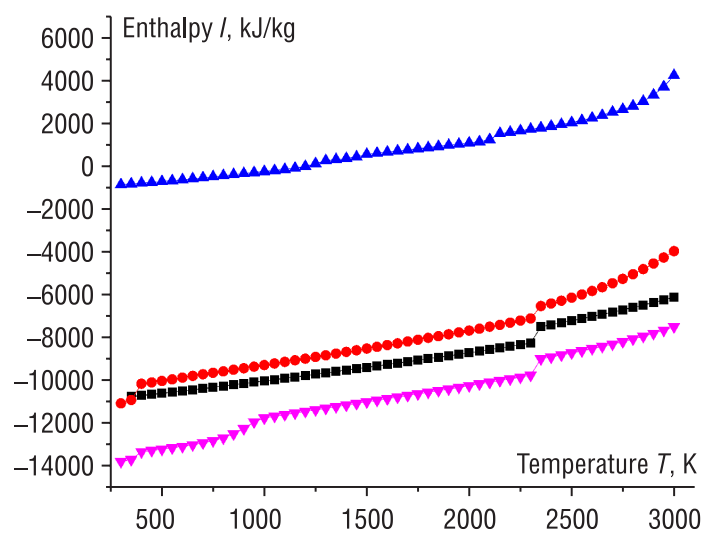

$\mathrm{Al}_{2} \mathrm{O}_{3}$-feedstock for FA-APS (ER $\left.=1.05\right)$

$\rightarrow \mathrm{Al}(\mathrm{OH})_{3}$-feedstock for FA-APS $(\mathrm{ER}=0.50)$

$-\mathrm{Cr}_{3} \mathrm{C}_{2}$-feedstock for FA-APS (ER $\left.=0.50\right)$

$\rightarrow\left(\mathrm{CO}_{2}+\mathrm{CH}_{4}\right)+\mathrm{Al}_{2} \mathrm{O}_{3}$-feedstock for FA-spray (fraction of $\mathrm{CH}_{4}=0.047$ )

Figure 6. Mass averaged enthalpies of the simulated $\mathrm{C}-\mathrm{H}-\mathrm{O}-\mathrm{N}-\mathrm{Ar}-\mathrm{Al}-, \mathrm{C}-\mathrm{H}-\mathrm{O}-\mathrm{N}-\mathrm{Ar}-\mathrm{Cr}-\mathrm{and} \mathrm{C}-\mathrm{H}-\mathrm{O}-\mathrm{Al}-\mathrm{systems}$ at the range of $T=300-3000 \mathrm{~K}\left(p=0.101 \mathrm{MPa}\right.$ ) for the regimes 2 (with $\mathrm{Al}_{2} \mathrm{O}_{3}$ feedstock), 4 (with $\mathrm{Al}(\mathrm{OH})_{3}$ feedstock), 7 (with $\mathrm{Cr}_{3} \mathrm{C}_{2}$ feedstock) and 9 (with $\mathrm{Al}_{2} \mathrm{O}_{3}$ feedstock) in the Table 
with LPG fuel for the heating of ceramic powders (especially, alumina) demonstrates the advantage of this FA-APS (in particular on the energy efficiencies and total energy consumption $E C$ ) in a comparison with the "basic" regimes of APS of the powders (in pure $\mathrm{N}_{2}$ plasma).

As a result for the cases of FA-APS with $\mathrm{Al}_{2} \mathrm{O}_{3}$-feedstock and with $\mathrm{Cr}_{3} \mathrm{C}_{2}$ one it was found that it is potentially possible to reach such enhanced level of the process productivity on the final products $G_{\mathrm{pr}}$ as close to 17 and $28 \mathrm{~kg} / \mathrm{h}$, respectively (at the moderate values of electric energy consumption $E C$, - near 1.8 and $1.0 \mathrm{kWh} / \mathrm{kg}$ (see the Figure 7, $a, d$ )). For these two powder heating cases the values of the required power of the torch (at $\left.\eta_{\mathrm{pl}}=0.8\right)$ are as the follows: $\geqslant 28.2$ and $\geqslant 22.3 \mathrm{~kW}$.

Energy consumption $E C, \mathrm{kWh} /(\mathrm{kg}$ of ceramic product)

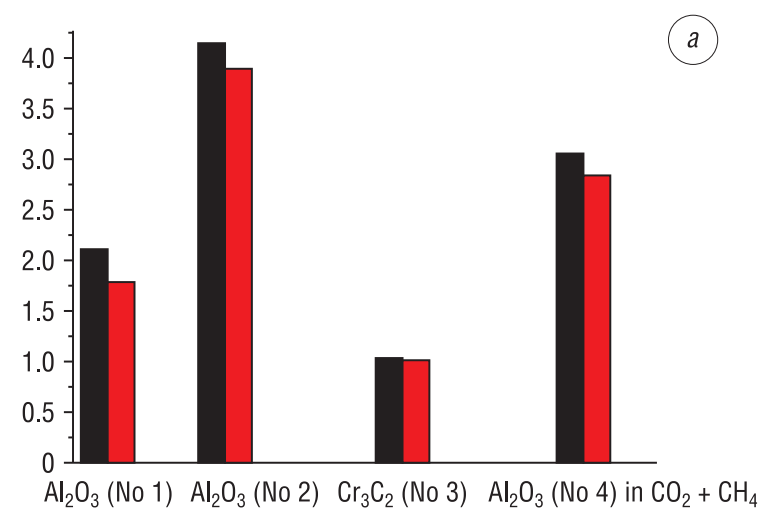

Energy efficiency EnE $E_{1}$

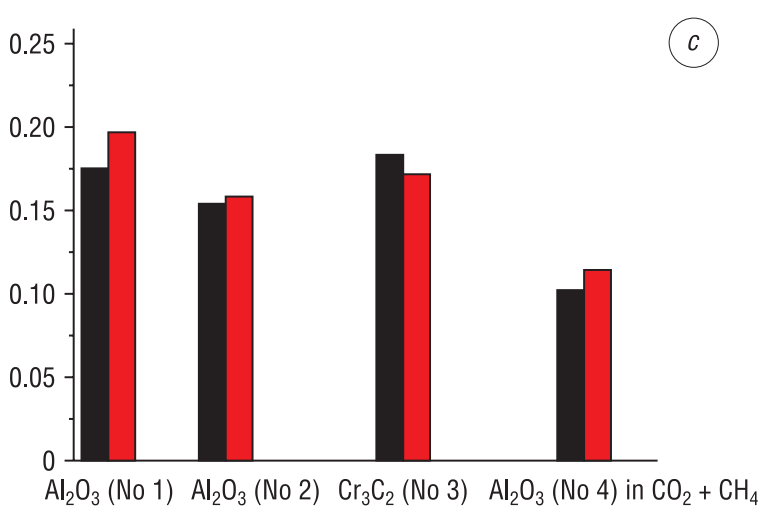

Minimal energy consumption for plasma torch operation $E C_{\mathrm{pt}}$,

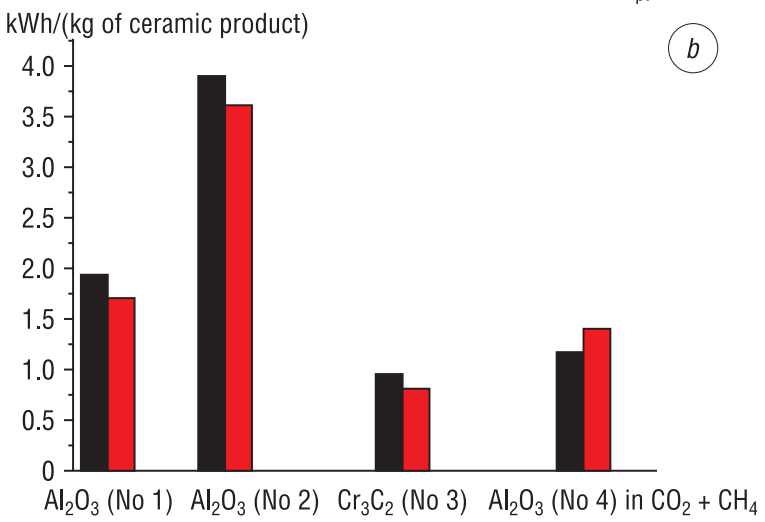

Productivity of plasma process on final ceramic product $G_{\mathrm{pr}}, \mathrm{kg} / \mathrm{h}$

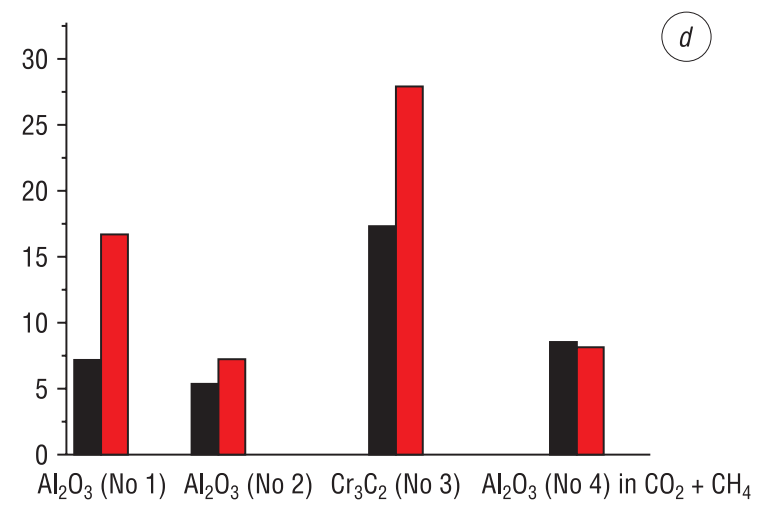

Basic regime of the process (APS in $\mathrm{N}_{2}$ )

Fuel assisted (FA) plasma process

Figure 7. Comparison of efficiency parameters for various cases of modeled $\mathrm{C}-\mathrm{H}-\mathrm{O}-\mathrm{N}-\mathrm{Ar}-\mathrm{Me}-$ and $\mathrm{C}-\mathrm{H}-\mathrm{O}-\mathrm{Al}-\mathrm{systems}$ : $a$ - comparison for energy consumption $E C ; b$ - comparison for energy consumption for plasma torch operation (ignoring the CPP' efficiency and with taking account of effect of $H H V$ of fuel in POA-APS-regimes as for combustion) $E C_{\mathrm{pt}}$; $c-$ comparison for $E n E_{1} ; d$ - comparison for the process productivity on the product. Here the red columns correspond to the following regimes in the Table: 1 - CA-APS with $\mathrm{Al}_{2} \mathrm{O}_{3}$-feedstock (regime 2), 2 - POA-APS with $\mathrm{Al}(\mathrm{OH})_{3}$-feedstock (regime 4), 3 - POA-APS with $\mathrm{Cr}_{3} \mathrm{C}_{2}$-feedstock (regime 6), 4 - FA-spray with $\mathrm{Al}_{2} \mathrm{O}_{3}$ in $\left(\mathrm{CO}_{2}+\mathrm{CH}_{4}\right.$ )-gas (regime 9); and the black columns correspond to the "basic" regimes of APS (with pure $\mathrm{N}_{2}$ medium $-3,5,8$ ) and for regime 10 for the mixture of

$$
\left(\mathrm{Al}_{2} \mathrm{O}_{3}+\mathrm{CO}_{2}+\mathrm{CH}_{4}\right)
$$

In accordance with obtained results for the variants of this group systems, it was also found that for the regimes simulating the heating of carbides (in particular, $\mathrm{Cr}_{3} \mathrm{C}_{2}$, - see regime 6 in the Table) in $\left(\mathrm{N}_{2}\right.$-air-LPG)-mixtures, the parameters of the process efficiency differ slightly from those for the conventional (clear-endothermal) regimes of their processing in $\mathrm{N}_{2}$ (in the spraying UPU-3D units $[1,3]$ ). For the case of processing regimes of $\mathrm{Al}(\mathrm{OH})_{3}$ hydroxide, they are explicitly worse than the CA-APS-variant with $\mathrm{Al}_{2} \mathrm{O}_{3}$-powder feedstock by the level of output efficiency parameters, but nevertheless, this variety of APS with dissociation-able $\mathrm{Al}(\mathrm{OH})_{3}$ feedstock will be quite promising due to very low prices for this material (only 0.6-2.0 US\$ $/ \mathrm{kg}$ ) [34], in a comparison with commercial $\mathrm{Al}_{2} \mathrm{O}_{3}$ powders for spraying. 
Conclusions. 1. The opportunity for upgrading of the industrial-type unit/system of atmospheric pressure for thermal spraying of ceramic powders with DC electric arc torch (30-40 kW power) by use of experimental variant of fuel gas-vortex intensifier was considered.

2. Special analysis of possible parameters of the produced mixed high-enthalpy flow after the plasma torch with this intensifier was performed based on thermodynamic calculations for the cases of $\mathrm{C}-\mathrm{H}-\mathrm{O}-\mathrm{N}-\mathrm{Ar}-\mathrm{Al}-, \mathrm{C}-\mathrm{H}-\mathrm{O}-\mathrm{N}-\mathrm{Ar}-\mathrm{Cr}-$, and $\mathrm{C}-\mathrm{H}-\mathrm{O}-\mathrm{Al}-$ systems in order to assess the potential of this system to modify the technology of oxide and carbide ceramic coatings formation. For the analyzed regimes, simulating spraying of alumina, they are 10-20\% superior in terms of the thermochemical characteristics of process to both the conventional method of powder heating during spraying in $\mathrm{N}_{2}$, and the new efficient variant under $\left(\mathrm{CO}_{2}+\mathrm{CH}_{4}\right)$-plasma conditions, proposed in recent years.

3. The case of proposed FA-APS with LPG fuel for the heating of ceramic powders (especially, alumina) demonstrates the advantage of this FA-APS (in particular on the energy efficiencies and $E C$ ) in a comparison with the "basic" regimes of APS of the powders (in $\mathrm{N}_{2}$ plasma). For the variants of FA-APS with alumina feedstock and for $\mathrm{Cr}_{3} \mathrm{C}_{2}$ feedstock powder it was found to be potentially possible to reach (at the moderate values of total electric energy consumption $E C$ for plasma torch and auxiliary equipment, - near 1.8 and $1.0 \mathrm{kWh} /(\mathrm{kg}$ of final ceramic product)) such enhanced level of the process productivity on the final product $G_{\mathrm{pr}}$ as approximately 17 and $28 \mathrm{~kg} / \mathrm{h}$, respectively.

\section{References}

1. Bielyi A. V., Kalinitchenko A.S., Kukareko V.A., Devoino O.G. Surface Engineering of Structural Materials with Using of Plasma and Beam Technologies. Minsk, Belorusskaya nauka Publ., 2017. 457 p. (in Russian).

2. Thermal spray coatings - global market trajectory \& analytics. Report, Apr. 2021, Global Industry Analysts, Inc., Available at: https://www.researchandmarkets.com/reports/5141523/thermal-spray-coatings-global-market-trajectory\#rela4-4479760 (accessed 20 June 2021).

3. Yatskevitch O. K. Technique for Formation of Wear-Resistant Ceramic Coatings by Plasma Spray of Alumina Powders Doped with Molybdenum and Boron. Minsk, BNTU, 2019. 176 p. (in Russian).

4. Pawlowski L. The Science and Engineering of Thermal Spray Coatings. Hoboken, NJ, USA, John Wiley \& Sons Publ., 2008. 647 p. https://doi.org/10.1002/9780470754085

5. Pershin L., Mitrasinovic A., Mostaghimi J. Treatment of refractory powders by a novel, high enthalpy dc plasma. Journal of Physics D: Applied Physics, 2013, vol. 46, no. 22, 224019. https://doi.org/10.1088/0022-3727/46/22/224019

6. Mostaghimi J., Pershin L., Salimijazi H., Nejad M., Ringuette M. Thermal spray copper alloy coatings as potent biocidal and virucidal surfaces. Journal of Thermal Spray Technology, 2021, vol. 30, no. 4, pp. 1-15. https://doi.org/10.1007/ s11666-021-01161-7

7. Kuzmin V., Gulyaev I., Sergachev D., Vaschenko S., Kornienko E., Tokarev A. Equipment and technologies of air-plasma spraying of functional coatings. MATEC Web of Conferences, 2017, vol. 129, pp. 01052. https://doi.org/10.1051/ matecconf/201712901052

8. Kornienko E.E., Mul' D. O., Rubtsova O. A., Vaschenko S.P., Kuzmin V.I., Gulyaev I. P., Sergachev D. V. Effect of plasma spraying regimes on structure and properties of $\mathrm{Ni}_{3} \mathrm{Al}$ coatings. Thermophysics and Aeromechanics, 2016, vol. 23, no. 6, pp. 919-928. https://doi.org/10.1134/S0869864316060147

9. Adán C., Marugán J., Grieken R.van, Chien K., Pershin L., Coyle T., Mostaghimi J. Effect of liquid feed-stock composition on the morphology of titanium dioxide films deposited by thermal plasma spray. Journal of Nanoscience and Nanotechnology, 2015, vol. 15, no. 9, pp. 6651-6662. https://doi.org/10.1166/jnn.2015.10874

10. Tekmen C., Iwata K., Tsunekawa Y., Okumiya M. Influence of methane and carbon dioxide on in-flight particle behavior of cast iron powder by atmospheric plasma spraying. Materials Letters, 2009, vol. 63, no. 28, pp. 2439-2441. https:// doi.org/10.1016/j.matlet.2009.08.026

11. Carnicer V., Orts M. J., Moreno R., Sánchez E. Engineering zirconia coating microstructures by using saccharides in aqueous suspension plasma spraying feedstocks. Ceramics International, 2020, vol. 46, no. 15, pp. 23749-23759. https://doi. org/10.1016/j.ceramint.2020.06.149

12. Carnicer V., Martinez-Julian F., Orts M.J., Sánchez V., Moreno R. Effect of fructose-containing feedstocks on the microstructure of multicomponent coatings deposited by suspension plasma spraying. Journal of the European Ceramic Society, 2019, vol. 39, no. 12, pp. 3433-3441. https://doi.org/10.1016/j.jeurceramsoc.2019.04.042

13. Yugeswaran S., Amarnath P., Ananthapadmanabhan P.V., Pershin L., Mostaghimi J., Chandra S., Coyle T.W. Thermal conductivity and oxidation behavior of porous Inconel 625 coating interface prepared by dual-injection plasma spraying. Surface and Coating Technology, 2021, vol. 411, pp. 126990. https://doi.org/10.1016/j.surfcoat.2021.126990 
14. Pateyron B., Calve N., Pawłowski L. Influence of water and ethanol on transport properties of the jets used in suspension plasma spraying. Surface and Coatings Technology, 2013. vol. 220, pp. 257-260. https://doi.org/10.1016/j.surfcoat.2012.10.010

15. Gorbunov A. V., Devoino O.G., Gorbunova V.A., Yatskevitch O.K., Koval V. A. Thermodynamic estimation of the parameters for the C-H-O-N-Me-systems as operating fluid simulants for new processes of powder thermal spraying and spheroidizing. Science and Technique. 2021, vol. 20, no. 5, pp. 390-398. https://doi.org/10.21122/22271031-2021-20-5-390-398

16. Halinouski A. A., Gorbunov A.V., Mosse A.L. Thermophysical and Power Parameters of DC Electric Arc Plasma Torches with $200 \mathrm{~kW}$ Power for the Reactors of Pyrolysis and Oxidation Pyrolysis of the Hydrocarbons. Minsk, A. V. Luikov Heat and Mass Transfer Institute of NAS of Belarus, 2007. 42 p. (in Russian).

17. Petrov S. V., Saakov A. G. Plasma of Combustion Products in Surface Engineering. Kyiv, TOPAS Publ., 2000.218 p. (in Russian).

18. Gadzhiev M.Kh., Tyuftyaev A.S., Kulikov Yu.M., Sargsyan M. A., Yusupov D. I., Son E.E. A Low-temperature plasma generator working on $\mathrm{N}_{2}$-propane mixture. Journal of Physics Conference Series, 2021, vol. 1787, no. 1, pp. 012060. https://doi.org/10.1088/1742-6596/1787/1/012060

19. Gorokhovski M., Karpenko E.I., Lockwood F.C., Messerle V.E., Trusov B. G., Ustimenko A.B. Plasma technologies for solid fuels: experiment and theory. Journal of the Energy Institute, 2005, vol. 78, no. 4, pp. 157-171. https://doi. org/10.1179/174602205x68261

20. Barbin N.M., Terentiev D. I., Alexeev S. G., Barbina T.M. Thermodynamic analysis of radionuclides behaviour in products of vapour phase hydrothermal oxidation of radioactive graphite. Journal of Radioanalytical and Nuclear Chemistry, 2015, vol. 307, no. 2, pp. 1459-1470. https://doi.org/10.1007/s10967-015-4587-2

21. Bublievsky A.F., Sagas J.C., Gorbunov A.V., Maciel H. S., Bublievsky D.A., Filho G.P., Lacava P.T., Halinouski A.A., Testoni G.E. Similarity relations of power-voltage characteristics for tornado gliding arc in plasma-assisted combustion processes. IEEE Transactions on Plasma Science, 2015, vol. 43, no. 5, pp. 1742-1746. https://doi.org/10.1109/ TPS.2015.2419822

22. Carpinlioglu M. O., Sanlisoy A. Performance assessment of plasma gasification for waste to energy conversion: A methodology for thermodynamic analysis. International Journal of Hydrogen Energy, 2018, vol. 43, no. 25, pp. 1149311504. https://doi.org/10.1016/j.ijhydene.2017.08.147

23. Mourão R., Marquesi A.R., Gorbunov A.V., Filho G.P., Halinouski A.A., Otani C. Thermochemical assessment of gasification process efficiency of biofuels industry waste with different plasma oxidants. IEEE Transactions on Plasma Science, 2015, vol. 43, no. 10, pp. 3760-3767. https://doi.org/10.1109/TPS.2015.2416129

24. Engel'sht V.S., Balan R.K. Chemical thermodynamics of the vapor-oxygen gasification of graphite. High Temperature, 2011, vol. 49, no. 5, pp. 736-743. https://doi.org/10.1134/S0018151X11050063

25. Zhukov M.F., Zasypkin I.M. Thermal Plasma Torches: Design, Characteristics and Applications. Cambridge, Cambridge International Science Publ., 2007. 596 p.

26. Oh S.-Y., Yun S., Kim J.-K. Process integration and design for maximizing energy efficiency of a coal-fired power plant integrated with amine-based $\mathrm{CO}_{2}$ capture process. Applied Energy, 2018, vol. 216, pp. 311-322. https://doi.org/10.1016/j. apenergy.2018.02.100

27. NIST Chemistry WebBook. Available at: https://webbook.nist.gov/cgi/cbook.cgi?ID=C74828\&Units=SI\&Mask=1\#T hermo-Gas (accessed 25 July 2021).

28. Zhou T., Francois B. Modeling and control design of hydrogen production process for an active hydrogen/wind hybrid power system. International Journal of Hydrogen Energy, 2009, vol. 34, no. 1, pp. 21-30. https://doi.org/10.1016/j. ijhydene.2008.10.030

29. Matveev I. B., Messerle V.E., Ustimenko A. B. Plasma gasification of coal in different oxidants. IEEE Transactions on Plasma Science, 2008, vol. 36, no. 6, pp. 2947-2954. https://doi.org/10.1109/TPS.2008.2007643

30. Brousse-Pereira E., Wittmann-Teneze K., Bianchi V., Longuet J.L., Del Campo L. Optical and electrical properties of heterogeneous coatings produced by aluminum powder and boehmite suspension plasma spraying. Journal of Thermal Spray Technology, 2012, vol. 21, no. 6, pp. 1110-1119. https://doi.org/10.1007/s11666-012-9792-8

31. Dolatabadi A., Mostaghimi J., Pershin V. Effect of a cylindrical shroud on particle conditions in high velocity oxy-fuel spray process. Science and Technology of Advanced Materials, 2002, vol. 137, no. 3, pp. 245-255. https://doi.org/10.1016/ S1468-6996(02)00023-2

32. Serena S., Raso M.A., Rodríguez M.A., Caballero A., Leo T.J. Thermodynamic evaluation of the $\mathrm{Al}_{2} \mathrm{O}_{3}-\mathrm{H}_{2} \mathrm{O}$ binary system at pressures up to $30 \mathrm{MPa}$. Ceramics International, 2009, vol. 35, no. 8, pp. 3081-3090. https://doi.org/10.1016/j. ceramint.2009.04.014

33. Lee H.W., Cha J.S., Park Y.-K. Catalytic co-pyrolysis of Kraft lignin with refuse-derived fuels using Ni-loaded ZSM-5 type catalysts. Catalysts, 2018, vol. 8, no. 11, p. 506. https://doi.org/10.3390/catal8110506

34. Aluminium Hydroxide, Industrial Grade, CAS No.: 21645-51-2, powder purity: $98 \%$ min. Available at: https://ditaichem.en.made-in-china.com/product/mSKEaPAxVBWi/China-High-Whiteness-Aluminum-Hydroxide-with-Lowest-Price. html (accessed 25 June 2021). 


\section{Information about the authors}

Oleg G. Devoino - Dr. Sc. (Engineering), Professor, Head of Plasma and Laser Technology Laboratory, Belarusian National Technical University (65, Nezavisimosti Ave., 220013, Minsk, Republic of Belarus). E-mail: devoino-o@, mail.ru

Andrei V. Gorbunov - Ph. D. (Engineering), Visiting Professor, Plasmas and Processes Laboratory, Aeronautics Institute of Technology, ITA-DCTA (São José dos Campos, 12228-900, SP, Brazil). Web of Science Researcher ID: R-2138-2019. E-mail: gorbunov.ita@gmail.com

Vera A. Gorbunova - Ph. D. (Chemistry), Assistant Professor, Department of Engineering Ecology, Belarusian National Technical University (65, Nezavisimosti Ave., 220013, Minsk, Republic of Belarus). E-mail: vgveragorbunova@ mail.ru

Aleksandr S. Volod'ko - Researcher, Plasma and Laser Technology Laboratory, Belarusian National Technical University (65, Nezavisimosti Ave., 220013, Minsk, Republic of Belarus). E-mail: nilusko@tut.by

Vitali A. Koval - Ph. D. (Engineering), Assistant Professor, Automotive and Tractor Faculty, Belarusian National Technical University (65, Nezavisimosti Ave., 220013, Minsk, Republic of Belarus). E-mail: vit_koval@mail.ru

Olga K. Yatskevich - Ph. D. (Engineering), Assistant Professor, Head of the Department of Technological Equipment, Belarusian National Technical University (65, Nezavisimosti Ave., 220013, Minsk, Republic of Belarus). E-mail: mtools@bntu.by

Anton A. Halinouski - Ph. D. (Engineering), Scientific Assistant, Department of Ionosphere and Aeronomy, Institute of Atmospheric Physics of the Czech Academy of Sciences (Boční II 1401 Prague 4, Czech Republic). Web of Science Researcher ID: X-6016-2018. E-mail: halinouski@ufa. cas.cz

\section{Информация об авторах}

Девойно Олег Георгиевич - доктор технических наук, профессор, заведующий отраслевой научно-исследовательской лабораторией плазменных и лазерных технологий, филиал БНТУ «Научно-исследовательский политехнический институт», Белорусский национальный технический университет (пр. Независимости, 65, 220013 , Минск, Республика Беларусь). E-mail: devoino-o@mail.ru

Горбунов Андрей Васильевич - кандидат технических наук, приглашенный профессор, лаборатория плазмы и процессов Факультета физики, Технологический институт аэронавтики (ITA-CTA, Сан-Жозе-дус-Кампос, 12228900, Сан Паулу, Бразилия). Web of Science Researcher ID: R-2138-2019. E-mail: gorbunov.ita@gmail.com

Горбунова Вера Алексеевна - кандидат химических наук, доцент, факультет горного дела и инженерной экологии, Белорусский национальный технический университет (пр. Независимости, 65, 220013, Минск, Республика Беларусь). E-mail: vgveragorbunova@mail.ru

Володько Александр Сергеевич - научный сотрудник, отраслевая научно-исследовательская лаборатория плазменных и лазерных технологий, филиал БНТУ «Научно-исследовательский политехнический институт», Белорусский национальный технический университет (пр. Независимости, 65, 220013, Минск, Республика Беларусь). E-mail: nilusko@tut.by

Коваль Виталий Александрович - кандидат технических наук, доцент, автотракторный факультет, Белорусский национальный технический университет (пр. Независимости, 65, 220013, Минск, Республика Беларусь). E-mail: vit_koval@mail.ru

Яикевич Ольга Константиновна - кандидат технических наук, доцент, заведующий кафедрой «Технологическое оборудование», машиностроительный факультет, Белорусский национальный технический университет (пр. Независимости, 65, 220013, Минск, Республика Беларусь). E-mail: mtools@bntu.by

Галиновский Антон Александрович - кандидат технических наук, научный сотрудник, Институт физики атмосферы Академии наук Чехии (Boční II 1401, Прага 4, Чешская Республика). Web of Science Researcher ID: X-6016-2018. E-mail: halinouski@ufa.cas.cz 